\title{
Report on the First Detection of Pectenotoxin-2, Spirolide-A and Their Derivatives in French Shellfish
}

\author{
Zouher Amzil ${ }^{1, *}$, Manoella Sibat ${ }^{1}$, Florence Royer ${ }^{1}$, Nadine Masson ${ }^{2}$ and Eric Abadie ${ }^{3}$ \\ ${ }^{1}$ IFREMER, Microbiology and Phycotoxins Department, BP 21105, 44311 Nantes, France; E-mails: \\ Manoella.Sibat@ifremer.fr,Florence.Royer@ifremer.fr \\ ${ }^{2}$ IFREMER, station d'Arcachon, Quai du Cdt Silhouette, 33120, Arcachon, France; E-mail: \\ Nadine.Masson@ifremer.fr, \\ ${ }^{3}$ IFREMER, station de Sète, Avenue Jean Monnet, BP 171, 34203, Sète, France; E-mail: \\ Eric.Abadie@ifremer.fr \\ * Corresponding author: E-mail: Zouher.Amzil@ifremer.fr; Phone: (33) 2-40-37-40-69; \\ Fax: (33) 2-40-37-40-73
}

Received: 16 October 2007 / Accepted: 21 November 2007 / Published: 23 November 2007

\begin{abstract}
In the context of the French Phytoplankton and Phycotoxins Monitoring Network (REPHY) programme, shellfish samples were harvested from different locations where harmful algae blooms were known to have occurred. For all shellfish samples found positive by the mouse bioassay for diarrhetic shellfish poisoning (DSP) toxins, liquid chromatography (LC) coupled with mass spectrometry (MS) was used to search for the following lipophilic toxins: okadaic acid (OA), dinophysistoxins (DTXs), pectenotoxins (PTXs), azaspiracids (AZAs), yessotoxins (YTXs), spirolides (SPXs) and gymnodimines (GYMs). In order to investigate the presence of acyl-OAs and/or acyl-DTX-1,-2 (DTX-3), alkaline hydrolysis was performed on all samples, and LC/MS analyses were carried out on the samples before and after hydrolysis. The results revealed different lipophilic toxin profiles as a function of the shellfish sampling location. The primary finding was that all of the samples contained OA and acyl-OA. In addition, other lipophilic toxins were found in shellfish samples: DTX-2, acyl-DTX-2 and SPXs (SPX-A, SPX-desMeC) on the Atlantic coast (Southern Brittany, Arcachon), and pectenotoxins (PTX-2, PTX-2-seco-acid and 7epi-PTX-2-seco-acid) on the Mediterranean coast (Thau lagoon, the island of Corsica). This paper reports on the first detection of PTX-2, SPX-A and their derivatives in French shellfish.
\end{abstract}


Keywords: DSP toxins, spirolides, pectenotoxins, LC/MS analysis

\section{Introduction}

Among toxin-related toxic phenomena, diarrhetic shellfish poisoning (DSP) represents a serious threat to both public health and the shellfish industry. Following the first episodes of DSP, the polyether lipophilic compounds okadaic acid (OA) and its methyl derivative, dinophysistoxin (DTX-1) were identified in toxic shellfish [1,2]. Congeners of these toxins, such as the OA isomer (DTX-2) [3] and a number of ester derivatives of OA, DTX-1 and DTX-2 were subsequently identified in shellfish [4-6]. Other toxins usually coexisting with OA analogues, but differing from them in terms of their chemical structures, include the pectenotoxins (PTXs) [7], the yessotoxins (YTXs) [8,9] and azaspiracids (AZAs) [10,11]. Other marine toxins were also identified - both spirolides (SPXs) and gymnodimines (GYMs) - in lipophilic extracts used for DSP toxin detection by mouse bioassay according to the modified Yasumoto method [12]. The presence of this group of compounds in shellfish was actually discovered because of the very high levels of acute toxicity induced in mice by i.p. injections of lipophilic extracts, causing rapid death in laboratory mice with neurotoxic symptoms (fast acting toxins, FAT). SPXs have been detected in shellfish in association with the dinoflagellate Alexandrium ostenfeldii, producing SPXs, firstly in North America [13-15] and then in Europe [1618]. GYMs have been detected in shellfish in association with Karenea selliformis firstly in New Zealand [19,20] and subsequently in Tunisia [21].

In France, among the toxic microalgae found along French coasts, three genera: Dinophysis, Alexandrium and Pseudo-nitzschia, have been specifically monitored [22-27]. When these algae are detected, the Phytoplankton and Phycotoxins Monitoring Network (REPHY) in charge of the French shellfish monitoring programme, performs toxicity analysis on exposed bivalves.

As regards lipophilic toxins, from the onset of a Dinophysis sp. outbreak, the REPHY proceeds with mouse bioassays for DSP toxin detection on a weekly basis throughout the risk period. The DSP mouse bioassay extraction protocol was initially optimised so as to adapt it for chemical analysis of mussel samples. Until 2003, the results of chemical analysis revealed the presence of OA and its derivative acyl-OA (DTX-3) in all samples, in proportions ranging from $50 \%$ to $100 \%$ of total OAequivalent concentration [27]. During 2004-2005, for all shellfish samples found positive by mouse bioassay for DSP toxins, liquid chromatography (LC) coupled with mass spectrometry (MS) was used to search for the following lipophilic toxins: OA, DTXs, PTXs, AZAs, YTXs, SPXs and GYMs. In order to investigate the presence of acyl-OA and/or acyls-DTX-1,-2 (DTX-3), alkaline hydrolysis was performed on all samples, and LC-MS/MS analyses were carried out on these samples before and after hydrolysis. This paper reports on the first recorded occurrence of PTX-2,SPX-A and their isomers in French shellfish. 


\section{Materials and methods}

Reference materials

Certified reference materials provided by IMB-Halifax, NS, Canada: i) standard solutions of OA, PTX-2, SPX-desMeC and GYM-A; ii) homogenate of mussel (MUS-2) containing OA and DTX-1. Irish mussel samples containing AZAs (AZA-1,-2,3) and Italian mussel samples containing YTXs (YTX, Homo-YTX, 45-YTX, 45-homo-YTX) were used to investigate these toxins without quantification.

\section{Shellfish samples}

During 2004-2005, several shellfish samples were collected at different production areas along the French coastline that had been previously closed due to the presence of lipophilic toxins. The shellfish samples were Mytilus edulis galloprovincialis, Crassostrea gigas, Cerastoderma edule, Ruditapes decussates and Donax trunculus. The samples had been collected by coastal laboratories in charge of the REPHY. For each type of sample, a minimum of $30 \mathrm{~g}$ of hepatopancreas (HP) was homogenized in a blender. Twenty g were used for the DSP mouse bioassay following the modified method of Yasumoto et al. [12]. The bioassay is regarded as positive if at least two out of three mice die within 24 hours. The remaining $10 \mathrm{~g}$ of HP homogenate were later used for LC-MS/MS analyses.

\section{Extraction procedure for lipophilic toxins}

Figure 1 shows the complete extraction procedure: lipophilic toxins were extracted from HP homogenate ( $2 \mathrm{~g}$ ) according to the DSP mouse-assay protocol, already optimized with MUS-2 reference material. The resulting $\mathrm{CH}_{2} \mathrm{Cl}_{2}$ phase was then dried and diluted in $\mathrm{MeOH}$. One aliquot was used for lipophilic toxins (except acyls-esters "DTX-3") analysis, and a second aliquot for DTX-3 alkaline hydrolysis to release OA, DTX-1, -2, and subsequent analysis of DTX3.

\section{LC/MS-MS analyses of lipophilic toxins}

For each shellfish sample, LC/MS-MS analyses were performed on two aliquots (before and after hydrolysis) in order to investigate lipophilic toxins as mentioned in Figure 1. Each aliquot (5 $\mu \mathrm{L})$ was injected into the LC/MS system using an Agilent 1100 LC model coupled to an API-2000 triple quadruple mass spectrometer equipped with a turbo-ionspray source. LC-MS-MS analyses were performed by modifying the Quilliam method [28]. Toxins were separated in a BDS-Hypersil C8 column (50 mm x $2 \mathrm{~mm}$ id, $3 \mu \mathrm{m}$ with a $10 \mathrm{~mm}$ guard cartridge) at $20^{\circ} \mathrm{C}$. The mobile phase was $100 \%$ water containing $2 \mathrm{mM}$ ammonium acetate and $50 \mathrm{mM}$ formic acid (channel A) and acetonitrile/water (95/5) containing $2 \mathrm{mM}$ ammonium acetate and $50 \mathrm{mM}$ formic acid (channel B). The analyses were carried out using a linear gradient elution, starting with 30-95\% B for $2.5 \mathrm{~min}$, followed by an $8 \mathrm{~min}$ hold at $95 \% \mathrm{~B}$ and 5\% A, and decreasing to $30 \%$ B over 0.5 min, which was held again for 5 min until 
the next run. The mobile phase flow-rate was set at $200 \mu \mathrm{L} \min ^{-1}$. The instrument control, data processing and analysis were conducted using Analyst software.

Figure 1: Extraction procedure for lipophilic toxin analysis by LC-MS/MS

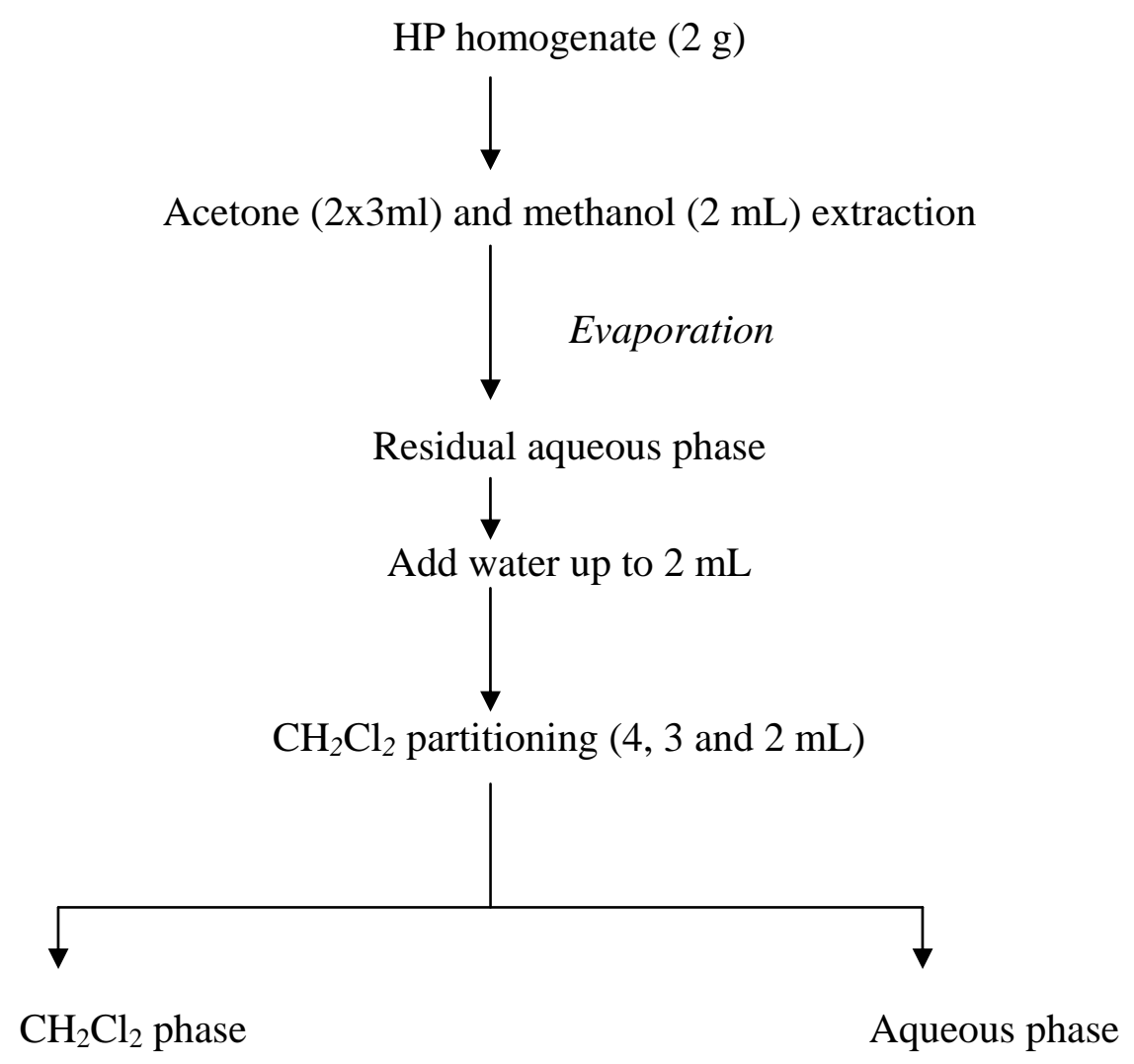

\section{Containing lipophilic toxins}

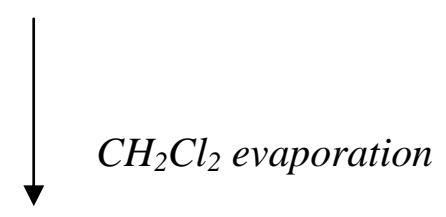

Dilution in $\mathrm{MeOH}(5 \mathrm{~mL})$

Aliquot filtrated on $0.2 \mu \mathrm{m}$

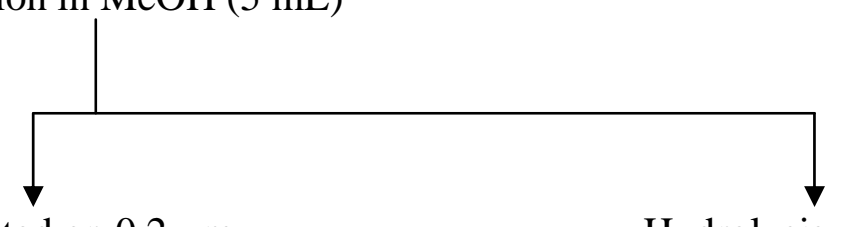

LC/MS analysis of OA, DTX-1,-2 (free forms)

PTXs, AZAs, YTXs, SPXs, GYMs
Hydrolysis of DTX-3 (1 mL)

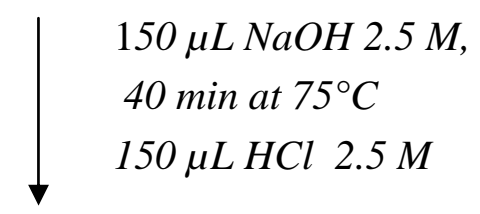

Aliquot filtrated on $0.2 \mu \mathrm{m}$

LC-MS/MS analysis of total OA, DTX-1,-2

(free and DTX-3 forms )

The electrospray ionization interface (ESI) was operated in both positive and negative modes using the following parameters: curtain gas: 19; temperature: 400; gas 1: 30; gas 2: 50; CAD gas: 5; Ion 
spray voltage: 5000. These parameters had been previously optimized using toxin standards. The mass spectrometer was operated in multiple reaction-monitoring (MRM), analyzing the two or three most intense product ions per compound. For ESI positive, the transitions selected were: $\left[\mathrm{M}+\mathrm{NH}_{4}\right]$ ions: OA and DTX-2, $\mathrm{m} / \mathrm{z}$ 822.5>787.5/769.5/751.5; DTX-1, $\mathrm{m} / \mathrm{z} \quad 836.5>818.5 / 800.5 ; \quad \mathrm{PTX}-2, \quad \mathrm{~m} / \mathrm{z}$ 876.5>823.5/841.5/805.5; PTX-2-sa and 7-epi-PTX-2-sa, m/z 894.5>841.5/805.5; [M+H] ions: SPX-A and SPX-desMeC, m/z 692.5>674.5/444/164; GYM-A, m/z 508.5>490.5/392.5, AZA-1, m/z 842.5>824.5/806.5/672.5; AZA-2, m/z 856.5>838.5/820.5; AZA-3, m/z 828.5>810.5/792.5. For ESI negative mode, the transition selected was: $[\mathrm{M}-\mathrm{H}]$ ions: YTX, m/z $1141.5>1061.5 / 855.5$; HomoYTX, m/z 1155.5>1075.5; 45-OH-YTX, m/z 1157.5>1077; 45-OH-HomoYTX, m/z 1171.5>1091.5.

\section{Results and Discussion}

During a DSP outbreak associated with Dinophysis sp. that occurred in France between 2004 and 2006, shellfish samples tested positive to the mouse bioassay for lipophilic toxins. Our report presents the results of extensive analysis of these shellfish samples harvested from different locations: the Atlantic coast (Brittany, Arcachon Bay) and the Mediterranean coast (Thau lagoon, Corsica). The study was carried out using the comprehensive LC-MS-based approach which enabled us to investigate the presence of OA together with a wide range of lipophilic toxins distributed in European seas. Figure 2 shows a LC-SM/SM chromatogram of a calibration solution of available certified standards.

Figure 2: Example of LC-MS/MS analysis of a calibration solution of certified standards.

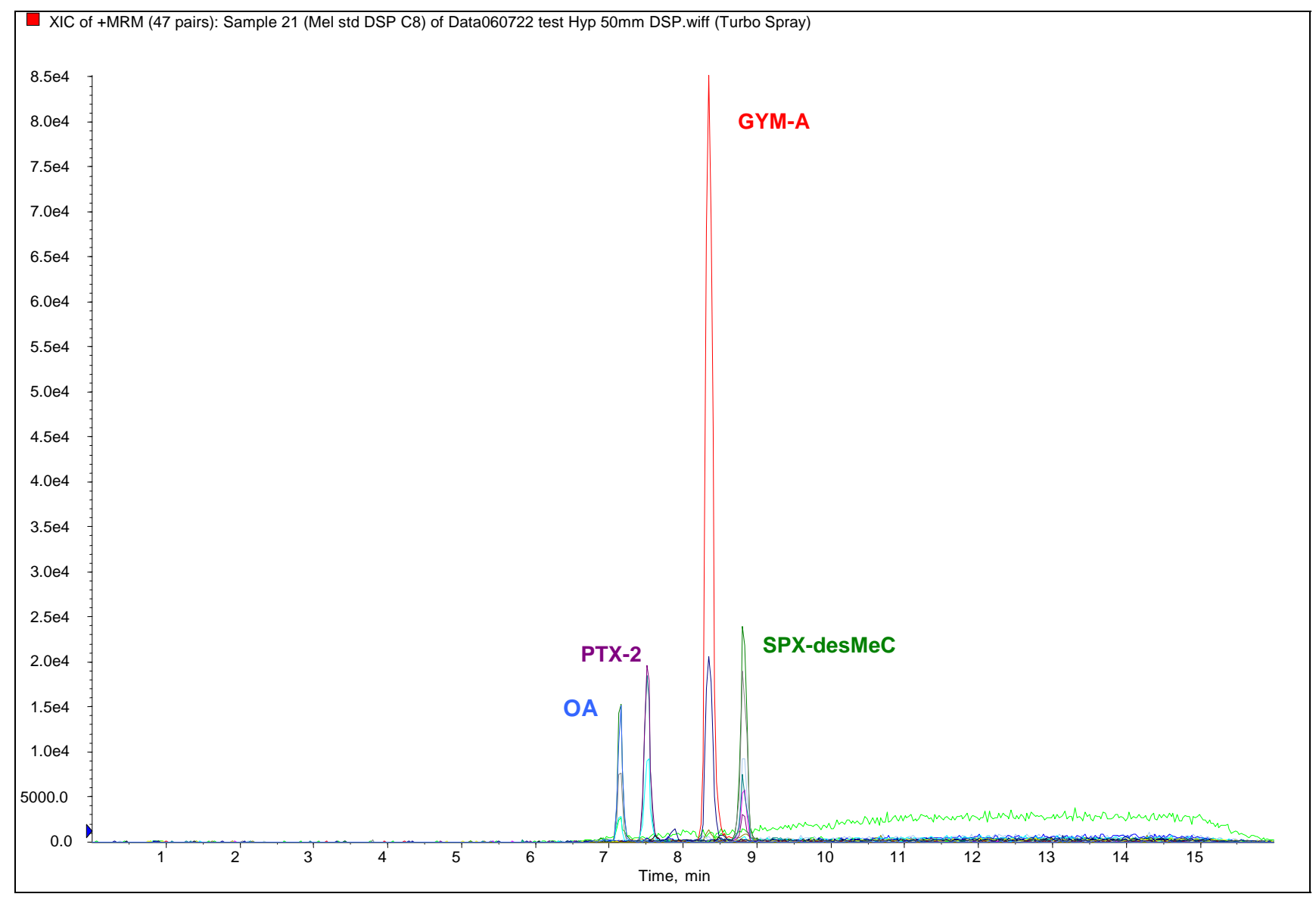


The primary finding was that all mouse-assayed shellfish samples contain OA and/or DTX-2 and their acyl-esters (DTX-3). DTX-1, YTXs, AZAs and GYMs toxins were not detected in all shellfish samples collected by REPHY.

Table 1 shows the lipophilic toxin profiles and maximum amounts obtained from shellfish analysed in three areas during the 2005 monitoring programme: South Brittany, the Atlantic coast (Arcachon) and the Mediterranean coast (Thau lagoon). The toxicity profile varies as a function of the region: OA and acyl-OA were found in shellfish in all three regions, apart from in oysters, which contain only the acyl-OA. For mussels and clams the proportion of acyl-OA is quite large, varying between 61 and 94\%. The DTX-2 is present in low concentrations in both forms (DTX-2, acyl-DTX-2) in clams harvested in South Brittany and in mussels from Arcachon. The proportion of acyl-DTX-2 varies from 26-40\%. The presence of OA, of DTX-2 and their acyls-esters, was linked to the presence of D. acuminata and D. acuta in South Brittany, and D. acuminata on the Atlantic coastline (Arcachon). French shellfish have been contaminated by OA since 1983, and by DTX-2 since 2003 $[24,29]$.

Table 1: Maximum amount of toxins in $\mu \mathrm{g} / \mathrm{Kg}$ of whole tissue found during the 2005 monitoring programme.

\begin{tabular}{|l|c|c|c|c|c|c|}
\hline & \multicolumn{2}{|c|}{ South Brittany } & \multicolumn{2}{c|}{$\begin{array}{c}\text { Atlantic coast } \\
\text { (Arcachon bay) }\end{array}$} & \multicolumn{2}{c|}{$\begin{array}{c}\text { Mediterranean coast } \\
\text { (Thau Lagoon) }\end{array}$} \\
\hline Lipophilic toxins & Clams & Mussels & Oysters & Mussels & Oysters & Mussels \\
\hline OA & 37 & 86 & $\mathrm{DL}^{\mathrm{a}}$ & 199 & $\mathrm{DL}^{\mathrm{a}}$ & 131 \\
Acyl-AO (DTX3) & 554 & 231 & 180 & 585 & 46 & 83 \\
DTX2 & 26 & $\mathrm{DL}^{\mathrm{a}}$ & $\mathrm{DL}^{\mathrm{a}}$ & 5 & $\mathrm{DL}^{\mathrm{a}}$ & $\mathrm{DL}^{\mathrm{a}}$ \\
Acyl-DTX-2 (DTX3) & 17 & $\mathrm{DL}^{\mathrm{a}}$ & $\mathrm{DL}^{\mathrm{a}}$ & 2 & $\mathrm{DL}^{\mathrm{a}}$ & $\mathrm{DL}^{\mathrm{a}}$ \\
PTX2 & 2 & $\mathrm{DL}^{\mathrm{b}}$ & 5 & 36 & 22 & 26 \\
PTX2-sa & 22 & $\mathrm{DL}^{\mathrm{b}}$ & 4 & 261 & 170 & 126 \\
7-epi-PTX2-sa & 16 & $\mathrm{DL}^{\mathrm{b}}$ & 2 & 94 & 33 & 116 \\
SPX-desMeC & 8 & 14 & 47 & 19 & $\mathrm{DL}^{\mathrm{c}}$ & $\mathrm{DL}^{\mathrm{c}}$ \\
SPX-A & $\mathrm{DL}$ & 7 & $\mathrm{DL}^{\mathrm{c}}$ & 68 & $\mathrm{DL}^{\mathrm{c}}$ & $\mathrm{DL}^{\mathrm{c}}$ \\
SPX-desMeD & 2 & 2 & $\mathrm{DL}^{\mathrm{c}}$ & $\mathrm{DL}^{\mathrm{c}}$ & $\mathrm{DL}^{\mathrm{c}}$ & $\mathrm{DL}^{\mathrm{c}}$ \\
\hline
\end{tabular}

${ }^{\text {a }}$ detection limit of AO group: $5 \mu \mathrm{g} / \mathrm{kg}$ of whole tissue.

${ }^{\mathrm{b}}$ detection limit of PTX-2 group: $4 \mu \mathrm{g} / \mathrm{kg}$ of whole tissue.

${ }^{\mathrm{c}}$ detection limit of SPX-desMeC group: $1 \mu \mathrm{g} / \mathrm{kg}$ of whole tissue.

The presence of PTX-2 and its derivatives were detected for the first time in France in 2004 in shellfish on the Mediterranean coast (Thau lagoon), and in 2005 in shellfish on the Atlantic coast (Arcachon) and South Brittany. Once accumulated in the shellfish flesh, smaller or larger proportions of the PTX-2 were subject to an enzymatic hydrolysis, manifesting in its transformation into PTX-2seco acid (PTX-2-sa and 7-epi-PTX-2-sa) [30]. For all the French samples analysed, the proportion of PTX-2 in the PTX-2-sa form varies by between 55 and 95\%, corroborating the research undertaken by 
Suzuki [31]. This contamination of shellfish by PTX-2 derivatives was linked to the presence of $D$. acuta and $D$. acuminata, which is known to produce PTX-2 [32-35]. Figure 3 shows various lipophilic toxin profiles of mussels from Atlantic and Mediterranean coasts analysed during the 2005 monitoring programme.

Figure 3. Lipophilic toxin profiles for different shellfish locations analysed during the 2005 monitoring programme

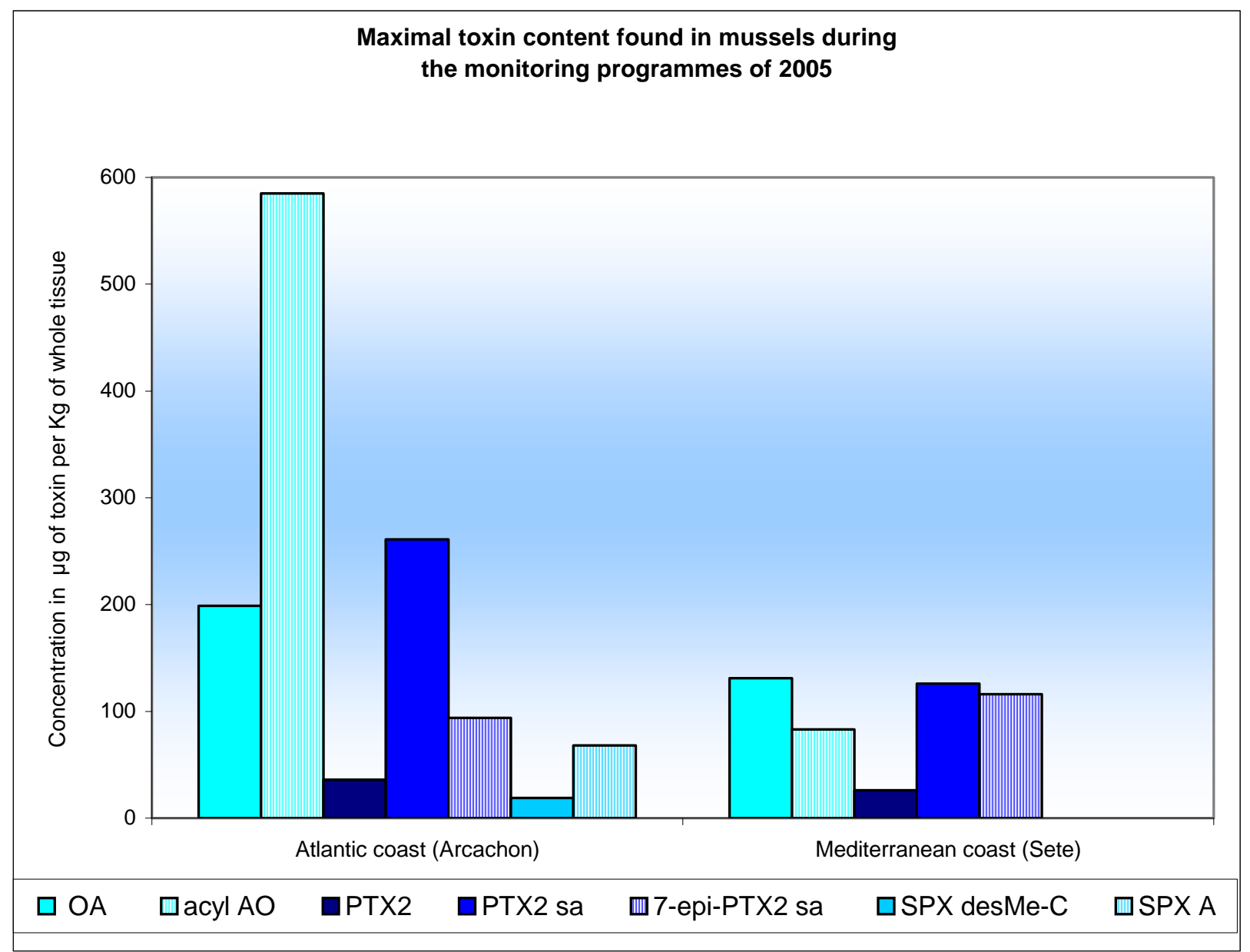

For Mediterranean shellfish samples (Thau lagoon) testing positive in the DSP bioassay, the concentrations of PTXs (PTX-2, PTX-2-sa and 7-epi-PTX-2-sa) were above the statutory thresholds (160 $\mathrm{\mu g}$ eq $\mathrm{OA} / \mathrm{Kg}$ of shellfish tissue). Figure 4 shows an example of LC-SM/SM analysis of PTX-2 derivatives in a $C$. gigas sample taken from Mediterranean coast.

For shellfish samples taken from Arcachon Bay (Atlantic coast), neurological symptoms and rapid deaths (in from 5 to 15 minutes) were observed in mice with shellfish samples tested according to the DSP bioassay. Neurotoxic effects on mice were due to the presence of SPXs (SPX-A, SPX-desMeC) detected for the first time in French shellfish in April 2005 (Figure 5). 
Figure 4. Example of LC-MS/MS analysis of PTX-2 derivatives in Crassostrea gigas from the Mediterranean coast.

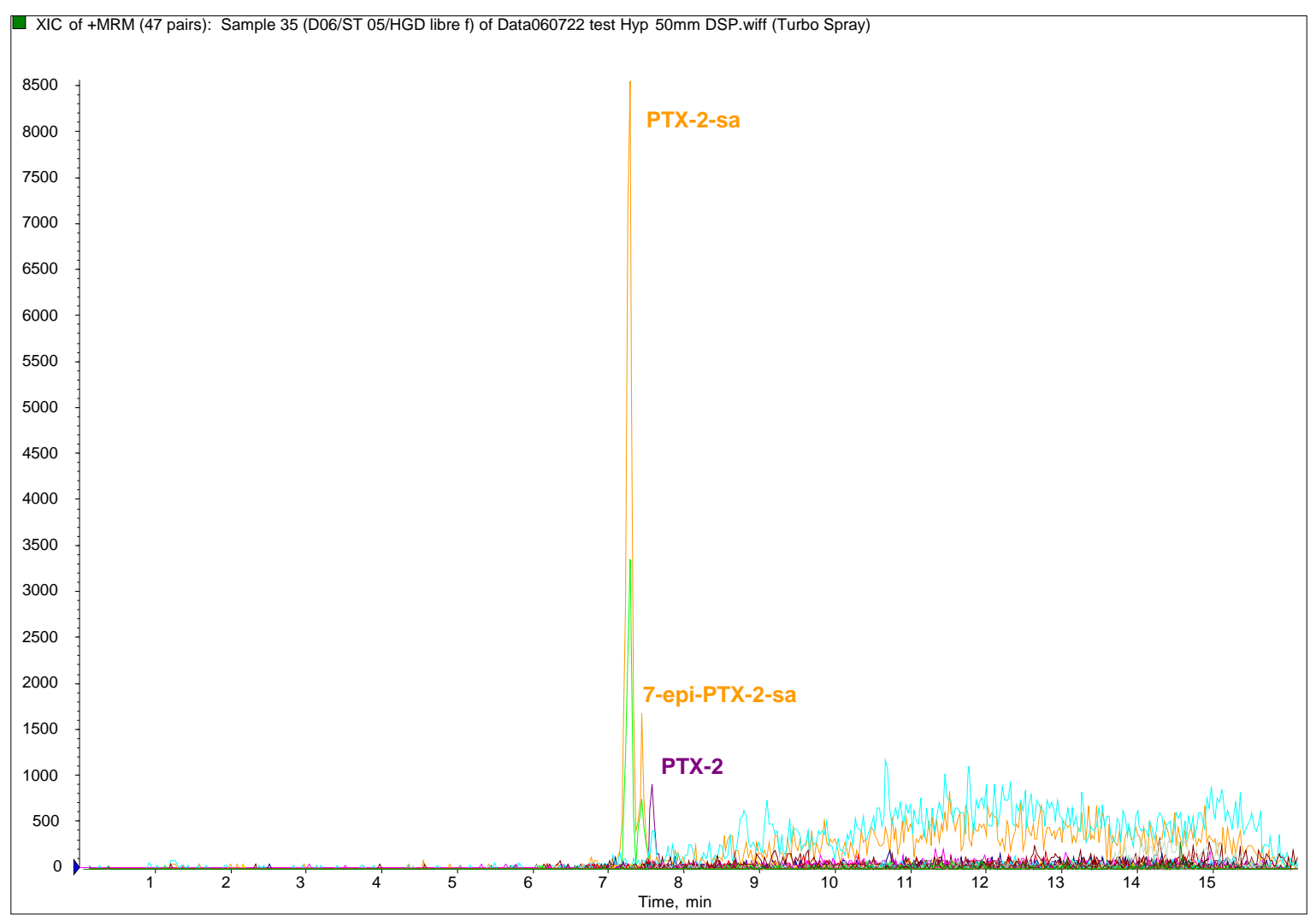

Figure 5. Example of LC-MS/MS analysis of lipophylic toxins in shellfish from the Bay of Arcachon.

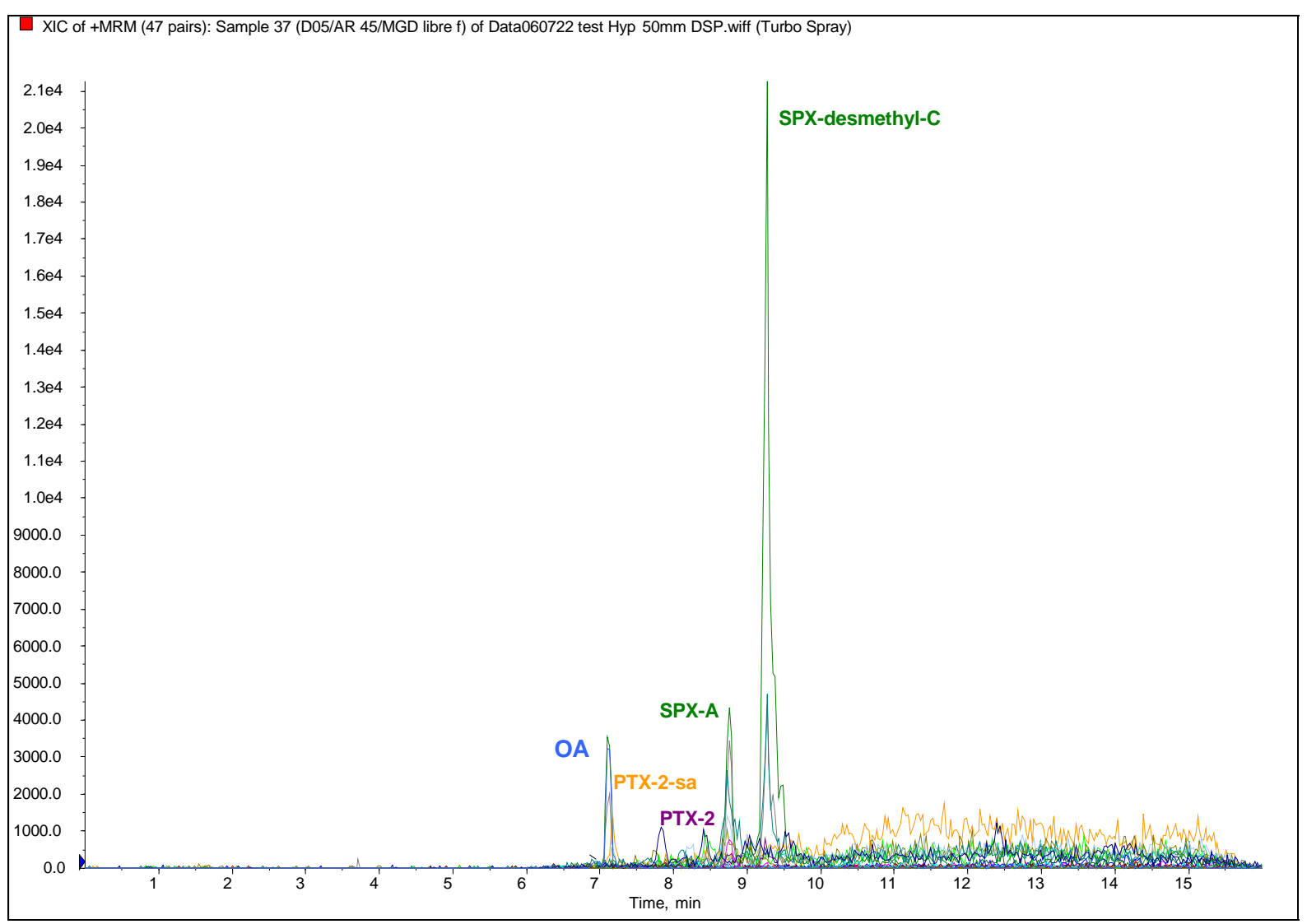


The concentration of SPXs, associated with the presence of A. ostenfeldii cells in sea water, was close to $60 \mu \mathrm{g} / \mathrm{kg}$ of shellfish tissue. In addition to SPXs, other DSP toxins were detected (OA, DTX-3, PTX-2, PTX-2-sa, 7-epi-PTX-2-sa), at levels well below the statutory thresholds, in association with the presence of D. accuminata. Lack of a European regulatory limit for SPXs and other appropriate toxicological data resulted in the shellfish areas in the bay of Arcachon being closed for 10 weeks as a precautionary measure.

This first observation has been followed up by other sightings of SPXs in trace quantities at other points along the French coastline, and particularly in South Brittany. On the international plane, SPXs are not regulated because we do not yet dispose of objective tools for assessing their toxicity for humans, in part because these toxins have been identified in the framework of shellfish monitoring programmes, rather than as a follow-up to human intoxication, notably in Canada [14,15] and in Norway [16].

\section{Conclusions}

Our results have revealed different lipophilic toxin profiles depending on the shellfish sampling location. The primary finding was that all of the samples contained OA and acyl-OA. In addition to these toxins, different lipophilic toxins were found depending on the shellfish area: i) DTX-2 and acylDTX-2 in southern Brittany; ii) PTX-2 derivatives along the Mediterranean coast (Thau lagoon, Corsica); iii) PTX-2, SPX-A and their derivatives on the Atlantic coast (Arcachon Bay). This study reports on the first occurrence of PTX-2, SPXs and associated derivatives in French shellfish. As regards SPXs, conclusive toxicological studies are required to elucidate the public health relevance of the different SPXs derivatives, and to provide a scientific basis for establishing regulatory control.

\section{Acknowledgements}

We would like to thank Myriam Rumebe, Claude Chiantella and Françoise Marco, from IFREMER coastal laboratories, for their invaluable assistance in this study.

\section{References}

1. Murata, M.; Shimatani, M.; Sugitani, H.; Oshima, Y.; Yasumoto, T. Isolation and structural elucidation of the causative toxin of diarrhetic shellfish poisoning. Bull. Jap. Soc. Fish. 1982, 48, 549-552.

2. Kumagai, M.; Yanagi, T.; Murata, M.; Yasumoto, T.; Kat, M.; Lassus, P.; Rodriguez-Vasquez, J.A. Okadaic acid as causative toxin of diarrhetic shellfish poisoning in Europe. Agric. Biol. Chem.1986, 50, 2853-2857.

3. Hu, T.; Doyle, J.; Jackson, D.; Marr, J.; Nixon, E.; Pleasance, S.; Quilliam, M.A.; Walter, J.A.; Writh, J.L.C. Isolation of a new diarrhetic shellfish poison from Irish mussels. Chem. Commun. 1992, 39-41. 
4. Marr, J.C.; Hu, T.; Pleasance, S.; Quilliam, M.A.; Wright, J.L.C. Detection of new 7-O-acyl derivatives of diarrhetic shellfish poisoning toxins by liquid chromatography-mass spectrometry. Toxicon 1992, 30, 1621-1630.

5. Vale, P.; Antonia, M.; Sampayo, M. Esters of okadaic acid related to human poisonings. Toxicon 1999, 37, 1109-1121.

6. Suzuki, T.; Ota, H.; Yamasaki, M. Direct evidence of transformation of dinophysistoxin-1 to 7-Oacyl-dinophysistoxin-1 (dinophysistoxin-3) in the scallop Patinopecten yessoensis. Toxicon 1999, 37, 187-198.

7. Yasumoto, T.; Murata, M.; Oshima, Y.; Sano, M.; Matsumoto, G.K.; Clardy, J. Diarrhetic shellfish toxins. Tetrahedron 1985, 41, 1019-1025.

8. Murata, M.; Kumagai, M.; Lee, J.S.; Yasumoto, T. Isolation and structure of yessotoxin, a polyether compound implicated in diarrhetic shellfish poisoning. Tetrahedron Lett. 1987, 28, 5869-5872.

9. Satake, M.; Mackenzie, L.; Yasumoto, T. Identification of Protoceratium reticulatum as the biogenetic origin of yessotoxin. Natural Toxins 1997, 5, 164-167.

10. Ofuji, K.; Satake, M.; McMahon, T.; James, K.J.; Naoki, H.; Oshima, Y.; Yasumoto, T. Two analogs of azaspiracids isolated from mussels, Mytilus edulis, involved in human intoxication in Ireland. Natural Toxins 1999, 7, 99- 102.

11. James, K.J.; Furey, A.; Lehane, M.; Ramstad, H.; Aune, T.; Hovgaard, P.; Morris, S.; Higman, W.; Satake, M.; Yasumoto, T. First evidence of an extensive northern European distribution of azaspiracid poisoning (AZP) toxins in shellfish. Toxicon 2002, 40, 909-915.

12. Yasumoto, T.; Murata, M.; Oshima, Y.; Matsumoto, G.K.; Clardy, J. Diarrhetic Shellfish Poisoning. In: Sea Food Toxins; Ragelis, E.P. (ed.); ACS Symposium Series: A.C.S.: Washington, DC, 1984; vol. 262, pp. 208-214.

13. Hu, T.; Curtis, J.M.; Oshima, Y.; Quilliam, M.A.; Walter, J.A.; Watson-Wright, W.M.; Wright, J.L.C. Spirolides B and D, two novel macrocycles isolated from the digestive glands of shellfish. J. Chem. Soc., Chem. Commun. 1995, 2159-2161.

14. Cembella, A.D.; Quilliam, M.A.; Lewis, N.I.; Bauder, A.G.; Wright J.L.C. Identifying the plankton origin and distribution of spirolides in coastal Nova Scotian waters. In Harmful Algae; Reguera B.; Blanco J.; Fernandez M.L.; Wyatt T. (Eds); Xunta de Galicia and Intergovernmental Oceanographic Commission of UNESCO, 1998; pp. 481-484.

15. Cembella, A.D.; Lewis, N.I.; Quilliam, M.A. The marine dinoflagellate Alexandrium ostenfeldii (Dinophyceae) as the causative organism of spirolides shellfish toxins, Phycologia 2000, 39, 6774.

16. Aasen, J.; Mackinnon, S.L.; Le Blanc, P.; Walter, J.A.; Hovgaard, P.; Aune, T.; Quilliam, M.A. Detection and identification of spirolides in Norwegian shellfish and plankton. Chem. Res. Toxicol. 2005, 18, 509-515.

17. Villar Gonzalez, A.; Rodriguez-Valasco, M.L.; Ben-Gigirey, B.; Botana, L.M. First evidence of spirolides in Spanish shellfish. Toxicon 2006, 48, 1068-1074.

18. Ciminiello, P.; Dell'Aversano, C.; Fattorusso, E.; Magno, S.; Tartaglione, L.; Cangini, M.; Pompei, M.; Guerrini, F.; Boni, L.; Pistochi, R. Toxin profile of Alexandrium ostenfeldii 
(Dinophyceae) from the Northern Adriatic sea revealed by liquid chromatography-mass spectrometry. Toxicon 2006, 47, 597-604.

19. MacKenzie, L.; Haywood, A.; Adamson, J.; Truman, P.; Till, D.; Deki, T.; Satake, M.; Yasumoto, T. Gymnodimine contamination of shellfish in New Zealand, In Harmful and toxic algal blooms; Yasumoto, T.; Oshima, Y.; Fukuyo, Y. (eds),; IOC of UNESCO Publish.: Paris, 1996; pp. 97-100.

20. McKenzie, L.; Beuzenberg, V.; McNabb, P. Production of gymnodimine by Karenia selliformis. (Haywood et al).; In: Harmful Algae 2002. Steidinger, K.A.; Landsberg, C.R.; Vargo, G.A (eds); Florida Fish and Wildlife Conservation Commission, Florida Institute of Aceanography, and IOC of UNESCO Publish: Paris; 2004; pp. 160-162.

21. Biré, R.; Krys, S.; Frémy, J.M.; Dragacci, S.; Stirling, D.; Kharrat, R. First evidence on occurrence of gymnodimine in clams from Tunisia, J. Nat. Toxins 2002, 11, 269-275.

22. Lassus, P.; Bardouil, M.; Berthome, J.P.; Maggi, P.; Truquet, P.; Le Dean, L. Seasonal occurrence of Dinophysis sp. along the French coast between 1983 and 1987. Aquat. Living Ressour 1988, 1, 155-164.

23. Lassus, P.; LeDoux, M.; Bardouil, M.; Bohec, M.; Erard-LeDenn, E. Kinetics of Alexandrium minitum Halim toxin accumulation in mussels and clams. Natural Toxins 1994, 2, 329-333.

24. Masselin, P.; Lassus, P.; Bardouil, M.. High performance liquid chromatography analysis of diarrhoeic toxins in Dinophysis spp. from the French coast. J. Appl. Phycol. 1992, 4, 385-389.

25. Masselin, P.; Amzil, Z.; Abadie, E.; Nézan, E.; Le Bec, C.; Chiantella, C.; Truquet, P. Paralytic shellfish poisoning on the French Mediterranean coast in the autumn 1998: Alexandrium tamarense complex (Dinophyceae) as causative agent. In Harmful Algal Blooms. Hallegraeff, G.M.; Blackburn, S.I.; Bolch, C.J.; Lewis R.J. (eds); JOC of UNESCO Publish.: Paris, 2001; pp., 407-410.

26. Amzil, Z.; Fresnel, J.; Le Gal, D.; Billard C. Domoic acid accumulation in french shellfish in relation to toxic species of Pseudo-nitzschia multiseries and P. pseudodelicatissima. Toxicon 2001, 39, 1245-1251,

27. Amzil, Z.; Mathias, A. First report on detection of okadaic acid 7-O-acyl-ester derivatives (DTX3) in French shellfish. In Molluscan Shellfish Safety. Henshilwood, K.; Deegan, B.; McMahon, T.; Cusak, C.; Keaveney, S.; Silke, J.; O’ Cinneide, M.; Lyons, D.; Hess P. (eds); The Marine Institute, Rinville, Oranmore, Galway, Ireland, 2006; pp. 150-161.

28. Quilliam, M. A.; Hess, P.; Dell'Aversano, C. Recent developments in the analysis of phycotoxins by liquid chromatography-mass spectrometry. In: Mycotoxins and Phycotoxins in Perspective at the Turn of the Millenium; De Koe, W.J.; Sampson, R.A.; Van Egmond, H.P.; Gilbert J.; Sabino, M. (eds.).; DeKoe W.J., Wageningen, The Netherlands, 2001; pp. 383-391.

29. Mondeguer, F.; Genin, E.; Mestre, G.; Nsengiyumva, C. Validation of an automated procedure of solid phase extraction of mussels digestive glands for identification and quantification of Dinophysistoxins in LC/ESI/MS2 by quadruple ion trap. In Molluscan Shellfish Safety. Henshilwood, K.; Deegan, B.; McMahon, T.; Cusak, C.; Keaveney, S.; Silke, J.; O’ Cinneide, M.; Lyons, D.; Hess P. (eds); The Marine Institute, Rinville, Oranmore, Galway, Ireland, 2006; pp. 94-99.

30. Miles, C.O.; Wilkins, A.L.; Munday, R.; Dines, M.H.; Hawkes, A.D.; Briggs, L.R.; Sandvik, M.; Jensen, D.J.; Cooney, J.M.; Holland, P.; Quilliam, M.A.; MacKenzie, A.L.; Beuzenberg, V.; 
Towers, N.R. Isolation of pectenotoxin-2 from Dinophysis acuta and its conversion to pectenotoxin-2 seco acid, and preliminary assessment of their acute toxicities. Toxicon 2004, 43, $1-9$.

31 Suzuki, T.; MacKenzie, L.; Stirling, D.; Adamson, J. Pectenotoxin-2 seco acid: a toxin converted from pectenotoxin-2 by the New Zealand Greenshell mussel, Pena canaliculus. Toxicon 2001, 39, 207-514.

32. McKenzie, L.; Beuzenberg, V.; Holland, P.; McNabb, P.; Suzuki, T.; Selwood, A. Pectenotoxin and okadaic acid-based toxin profiles in Dinophysis acuta and Dinophysis acuminata from New Zealand. Harmful Algae 2005, 4, 75-85.

33. Vrancic, M.P.; Mestrovic, V.; Marasovic, I.; Gillman, M.; Furey, A.; James K.K. The occurrence of 7-epi-pectenotoxin-2 seco acid in the coastal waters of the central Adriatic (Kastela Bay). Toxicon 2001, 39, 771-779.

34. Vale, P.; De Sampayo, M.A. Pectenotoxin-2 seco acid, 7-epi-pectenotoxin-2 seco acid and pectenotoxin-2 in shellfish and plankton from Portugal. Toxicon 2002, 40, 972-987.

35. Blanco, J.; Alvarez, G.; Uribe, E. Identification of pectenotoxins in plankton, filter feeders, and isolated cells of a Dinophysis acuminata with an atypical toxin profile, from Chile. Toxicon 2007, 49, 710-716.

Sample Availability: Contact the authors.

(C) 2007 by MDPI (http://www.mdpi.org). Reproduction is permitted for noncommercial purposes. 